\title{
Productivity or Employment: Is It a Choice?
}

\author{
Andrea De Michelis \\ Federal Reserve Board \\ Marcello Estevão \\ International Monetary Fund \\ Beth Anne Wilson ${ }^{1}$ \\ Federal Reserve Board
}

\begin{abstract}
Traditionally, shocks to total factor productivity (TFP) are considered exogenous and the response of employment is determined by their effect on aggregate demand. We approach the relationship between TFP and labour input differently, raising the possibility that in response to labour supply shocks firms adjust production efficiency. TFP would, thus, be endogenous to firms' production decisions. We present cross-country evidence of a strong negative correlation between growth in TFP and labour inputs over the medium to long run. This result is robust to changing datasets, sample periods, and industry composition. To address the question of causality, we use instruments to capture changes in hours worked that are independent of TFP movements and find that TFP growth falls (increases) following a pickup (decline) in hours growth. These results have important policy implications.
\end{abstract}

\section{RÉSUMÉ}

Traditionnellement, les chocs de la productivité totale des facteurs (PTF) sont considérés exogènes, et la réponse de l'emploi est déterminée par leur effet sur la demande agrégée. Nous abordons la relation entre la PTF et l'apport de travail différemment, en soulevant la possibilité qu'étant donné les chocs sur l'offre de main-d'œuvre, les entreprises réduisent leurs efforts visant à accroître l'efficacité. La PTF serait par conséquent endogène aux décisions de production des entreprises. Nous présentons des preuves, sur plusieurs pays, d'une forte corrélation négative entre la croissance de la PTF et les intrants de travail à moyen et à long terme. Ce résultat résiste à l'évolution des ensembles de données, des périodes d'échantillonnage et de la composition des industries. Pour remédier à la question de la causalité, nous utilisons des instruments pour saisir l'évolution des heures travaillées indépendament des mouvements de la PTF et constatons que la croissance de la PTF diminue à la suite d'un gain de la croissance du nombre d'heures. Ces résultats ont d'importantes incidences de politique.

1 Andrea De Michelis is a Senior Economist in the International Finance Division at the Federal Reserve Board. Marcello Estevão is a Mission Chief at the International Monetary Fund. Beth Anne Wilson is an Assistant Director in the International Finance Division at the Federal Reserve Board. We thank Rebecca Spavins and Daniel Van Deusen for excellent research assistance, and benefited from comments of Barbara Fraumeni, Andrea Raffo, Andrew Sharpe, participants at the 2013 AEA meetings, and an anonymous referee. The views in this paper are solely the responsibility of the authors and should not be interpreted as reflecting the views of the Board of Governors of the Federal Reserve System, the International Monetary Fund, or any other person associated with either institution. Email: andrea.demichelis@frb.gov, mestevao@imf.org, bethanne.wilson@frb.gov. 
OVER THE PAST DECADE, policymakers in Canada have expressed concern about the country's slow rate of productivity growth. Indeed, total factor productivity (TFP) growth in Canada has consistently underperformed that of the other G-7 economies. Output growth, however, has been relatively stronger, reflecting a higher-than-average pace of employment growth over the last 40 years. Given the strong performance of output, how worried should policymakers be about the weaker TFP growth? In traditional economic theory, changes in TFP are a key driver of economic growth and, to a great extent, are considered exogenous. However, the experience of Canada leads to questions about the traditional view. More specifically, could TFP respond endogenously to the availability of labour? Instead of taking TFP as given, can firms and industries vary TFP and employment depending on factor endowment and labour costs essentially "choosing" an optimal tradeoff between TFP and labour intensity on the production frontier?

In this article, we examine the exogeneity of TFP to changes in labour use in the production process. We begin by establishing a negative historical relationship between productivity and labour input across industrial countries. In particular, we find a negative correlation between TFP growth and hours growth from 1970 to 2007 across the main OECD economies. Countries that have stronger growth rates of TFP tend to have lower hours growth. This result is robust across databases, holds up over smaller time periods, is not driven by the business cycle, and does not reflect differences in industry composition across countries. Related research documents a similar relationship between labour productivity and labour input, although in this case the negative correlation is expected to be temporary and part of the hiring and firing process (Estevão, 2007, and Dew-Becker and Gordon, 2012). Nonetheless, we document that all the basic results showing a negative relationship between TFP growth and hours growth in themedium-tolong run remain if labour productivity growth is used to measure changes in production efficiency.

We then turn to the question of causality. While it is difficult to believe that countries such as Canada, the United States, and Germany have significantly different technological capacity or knowledge, they do have different labour endowments, immigration policies, regulations, and tax policies. We exploit these differences to assess the response of TFP growth to exogenous movements in labour supply. In particular, we instrument for the growth in hours using taxes and population growth, both of which should be independent of TFP. Using these instruments, we find a continued significant negative correlation between TFP growth and growth in total hours; a result that is robust to many variations, including using labour productivity growth as a proxy for changes in production efficiency and dropping particular countries from the sample. ${ }^{2}$

These results raise interesting and important policy questions. For instance, should countries with strong employment growth,

2 Measurement issues could also be behind some of the differences in TFP growth across countries in our sample. For instance, Diewert and Yu (2012) argue that TFP growth could have averaged 1.0 per cent from 1961 to 2011 in Canada, as opposed to the 0.3 per cent calculated by Statistics Canada. The authors arrived to this conclusion by estimating a much slower capital services growth for a given GDP growth path than implied by the official series. This adjustment puts Canada nearer to the middle of the TFP range for our sample and time period, but it does not invalidate the main finding of this article. More generally, the negative relationship between TFP growth and hours growth does not appear to depend on the experience of a particular country or particular measurement errors. 
Table 1

Data Sources

\begin{tabular}{|c|c|c|c|c|c|}
\hline \multicolumn{2}{|c|}{ Database } & Sectoral Data & Variable Coverage & Country Coverage & Period Coverage \\
\hline \multicolumn{2}{|c|}{$\begin{array}{l}\text { Conference Board: } \\
\text { Total Economy Database }\end{array}$} & No & $\begin{array}{c}\text { Total Employment } \\
\text { Total Hours Worked } \\
\text { Population } \\
\text { TFP }\end{array}$ & $\begin{array}{l}\text { Australia, Austria, Belgium, } \\
\text { Canada, Denmark, Finland, } \\
\text { France, Germany, Greece, Italy, } \\
\text { Japan, Netherlands, New Zealand, } \\
\text { Norway, Portugal, Spain, Sweden, } \\
\text { Switzerland, United Kingdom, } \\
\text { United States }\end{array}$ & $\begin{array}{l}1950-2011 \\
(1970-2011 \text { for } \\
\text { TFP })\end{array}$ \\
\hline \multirow[b]{2}{*}{ KLEMS } & EU & \multirow[b]{2}{*}{ Yes } & \multirow{2}{*}{$\begin{array}{c}\text { Total Employment } \\
\text { Total Hours Worked } \\
\text { TFP }\end{array}$} & $\begin{array}{l}\text { Australia, Belgium, Denmark, } \\
\text { Finland, Japan, Netherlands }\end{array}$ & \multirow[b]{2}{*}{$1980-2007$} \\
\hline & World & & & $\begin{array}{l}\text { Austria, Canada, France, Germany, } \\
\text { Italy, Spain, United Kingdom, } \\
\text { United States }\end{array}$ & \\
\hline \multicolumn{2}{|l|}{ AMECO } & No & $\begin{array}{l}\text { Total Employment } \\
\text { TFP }\end{array}$ & $\begin{array}{l}\text { Canada, France, Germany, Italy, } \\
\text { Japan, United Kingdom, United } \\
\text { States }\end{array}$ & $1960-2013$ \\
\hline \multicolumn{2}{|c|}{ United Nations } & No & Population & $\begin{array}{l}\text { Australia, Austria, Belgium, } \\
\text { Canada, Denmark, Finland, } \\
\text { France, Germany, Greece, Italy, } \\
\text { Japan, Netherlands, New Zealand, } \\
\text { Norway, Portugal, Spain, Sweden, } \\
\text { Switzerland, United Kingdom, } \\
\text { United States }\end{array}$ & $1950-2020$ \\
\hline \multicolumn{2}{|c|}{ McDaniel } & No & Tax rates & $\begin{array}{l}\text { Australia, Austria, Belgium, } \\
\text { Canada, Finland, France, Germany, } \\
\text { Italy, Japan, Netherlands, Spain, } \\
\text { Sweden, Switzerland, United } \\
\text { Kingdom, United States }\end{array}$ & $1950-2010$ \\
\hline
\end{tabular}

such as Canada, worry less about their relatively weaker TFP? To what extent can policy influence the tradeoff between TFP and labour usage? And are there social welfare implications for such a choice? In response to aging populations, will countries experience rising TFP as firms find ways to utilize existing workers more effectively? The case of Japan, with its low employment growth and relatively weak TFP growth, suggests other factors may be at play. Therefore, can policies such as increasing labour and product market flexibility influence the ease with which industries can move from one TFP/labour mix to another in response to shocks?

The first section of the article describes the datasets used. Section two presents our results while section three discusses additional robustness checks. The fourth and final section concludes with a discussion of the implications of our results for policy and future research.

\section{Data Sources}

To examine the relationship between productivity and labour input, we use several databases that allow for cross-country comparisons over long time periods. The main data sources are the Total Economy Database (TED) from the Conference Board and World KLEMS (Table 1). Both databases provide cross-country measures of output and input (such as GDP, employment, and hours) as well as derived variables (such as TFP) using standard growth accounting methodology. TED is constructed to enhance international comparability and spans over 123 countries from 1950 to 2011. While TED contains information only for the aggregate economy, World KLEMS also includes a breakdown at the industry level. However, World KLEMS generally covers only the 1980-2009 period and data for some countries of interest are missing or incomplete; moreover, the dataset is still a 


\section{Chart 1}

Relationship between TFP Growth and Hours Growth, 19702007

(average annual rate of change)



Chart 2

Relationship between TFP Growth and Employment Growth, 1970-2007

(average annual rate of change)

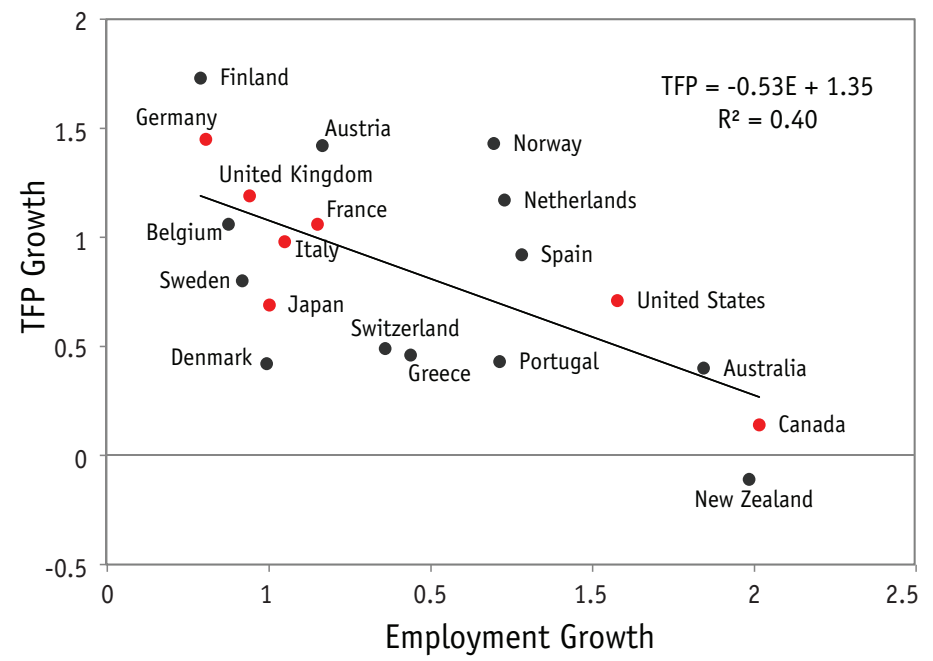

work in progress and thus international comparability is more problematic. To address some of these limitations, we integrate World KLEMS with data from the original European Union (EU) KLEMS initiative, which focused on European countries and for which data are available only up to $2007 .{ }^{3} \mathrm{We}$ also use the EU AMECO dataset to check for the robustness of some results.

In our baseline analysis, we examine 20 OECD-member countries over the period 1970-2007. ${ }^{4}$ Though data for a few additional countries are available, we restrict our analysis to a set of countries which we consider to be relatively close to their respective technical frontiers and thus for which it is reasonable to discuss a tradeoff between employment and technology growth. We also do not consider the Great Recession and subsequent recovery in our baseline case, in part because data would not be available for some countries but also because our study focuses on a long-run relationship. That said, although the dynamics of TFP, employment, and hours have been different than typically seen during recessions - particularly because of the depth of the recession and evidence of greater-than-usual labour hoarding by firms in some countries, as documented in van Ark et al. (2011) - our main results hold if we extend our analysis beyond the Great Recession.

We also used data on population and taxes (Table 1). Population estimates come from TED and the United Nations (UN) Department of Economic and Social Affairs. Tax data come from the 2010 update of McDaniel (2007).

3 TED, World KLEMS, and EU KLEMS are all publically available at http://www.conference-board.org/data/economydatabase, http://www.worldklems.net, and www.euklems.net, respectively. For a review of how these datasets have been assembled and used, see van Ark et al. (2011), Jorgenson (2012), Jorgenson et al. (2010), 0 'Mahony and Timmer (2009), and Timmer et al. (2010).

4 Country coverage for Austria, Canada, France, Germany, Italy, Spain, the United Kingdom, and the United States is available in World KLEMS. EU KLEMS is used to supplement this list, adding Australia, Belgium, Denmark, Finland, Japan, and the Netherlands to the dataset. Data for these 14 countries and an additional six (Greece, New Zealand, Norway, Portugal, Sweden, and Switzerland) from 1970-2011 are included in TED, though only at the total economy level. 


\section{Results: Negative Link between TFP Growth and Labour Input Growth}

\section{Basic results and some robustness tests}

Using the data described above, we begin by calculating the simple long-run relationship between TFP and labour input for the countries in our sample. Chart 1 shows a scatter plot of the average annual per cent change in TFP on the per cent change in total hours for 20 OECD countries from 1970 to 2007 using TED. The fitted line through the country averages shows a negative relationship, with a 1 percentage-point increase in the growth rate of hours related to a 0.5 percentage-point decline in TFP growth. The relationship holds when only the G-7 countries are included, shown in red, suggesting that the most advanced economies - the countries closest to the technological frontier - have variation in TFP growth that is negatively related to labour input.

This negative relationship is robust to a broad range of factors. First, although we have chosen to use the most comprehensive measure of labour input - total hours - in our calculations, there is also a negative correlation between TFP growth and employment growth of roughly the same magnitude (Chart 2). TFP growth is also negatively correlated with the rate of change of hours per capita (not shown), but we expressly chose to not conduct our analysis in per capita terms because, as we will argue later, population growth may be one of the factors driving the tradeoff between productivity and labour input.

Second, measurement issues are always a concern when calculating an unobservable or residual such as TFP. Indeed, TFP measures tend to be pro-cyclical, as labour hoarding at the beginning of recessions depresses observed TFP, while a more intensive use of incumbent workers during the initial phase of expansions boosts
Table 2

Labour Input Growth versus TFP Growth by Database

\begin{tabular}{l|c|c|c|c}
$\begin{array}{l}\text { Database } \\
\text { Input }\end{array}$ & $\begin{array}{c}\text { TED } \\
\text { Employment }\end{array}$ & $\begin{array}{c}\text { KLEMS }{ }^{1} \\
\text { Employment }\end{array}$ & $\begin{array}{c}\text { TED } \\
\text { Hours }\end{array}$ & $\begin{array}{c}\text { KLEMS }{ }^{1} \\
\text { Hours }\end{array}$ \\
\hline \multirow{2}{*}{ Constant } & $1.35^{* * *}$ & $0.86^{* * *}$ & $1.07^{* * *}$ & $0.74^{* * *}$ \\
\cline { 2 - 5 } & $(0.17)$ & $(0.18)$ & $(0.10)$ & -0.12 \\
\hline Coefficient & $-0.53^{* * *}$ & $-0.36^{*}$ & $-0.49^{* * *}$ & $-0.37^{* *}$ \\
\cline { 2 - 5 } & $(0.15)$ & $(0.17)$ & $(0.11)$ & $(-0.09)$ \\
\hline Observations & 20 & 14 & 20 & 14 \\
\hline Adjusted R $\mathrm{R}^{2}$ & 0.36 & 0.21 & 0.48 & 0.33 \\
\hline
\end{tabular}

1 KLEMS data span the 1980-2007 period; TED data span the 1970-2007 period.

Standard errors in parentheses. ${ }^{* *} p<0.01,{ }^{*} \mathrm{p} p<0.05,{ }^{*} p<0.1$

Sources: Total Economy Database, EU KLEMS, and World KLEMS.

\section{Table 3}

\section{Hours Growth versus TFP Growth by Period}

\begin{tabular}{l|c|c|c|c|c} 
Period & $1970-2007$ & $1970 \mathrm{~s}$ & $1980 \mathrm{~s}$ & $1990 \mathrm{~s}$ & $\mathbf{2 0 0 0 - 2 0 0 7}$ \\
\hline \multirow{2}{*}{ Constant } & $1.07^{* * *}$ & $1.67^{* * *}$ & $1.01^{* * *}$ & $0.60^{* * *}$ & $0.91^{* * *}$ \\
\cline { 2 - 6 } & $(0.10)$ & $(0.13)$ & $(0.13)$ & $(0.15)$ & $(0.22)$ \\
\hline \multirow{2}{*}{ Hours Growth } & $-0.49^{* * *}$ & $-0.57^{* * *}$ & $-0.41^{* * *}$ & -0.19 & $-0.63^{* * *}$ \\
\cline { 2 - 6 } & $(0.11)$ & $(0.13)$ & $(0.13)$ & $(0.18)$ & $(0.18)$ \\
\hline Observations & 20 & 20 & 20 & 20 & 20 \\
\hline Adjusted R & 0.48 & 0.49 & 0.33 & 0.01 & 0.36 \\
\hline
\end{tabular}

Standard errors in parentheses. ${ }^{* *} p<0.01,{ }^{* *} p<0.05,{ }^{*} p<0.1$

Source: Total Economy Database.

measured TFP (Comin, 2008, and Basu, 1996). Cyclical changes in the quality of the employed pool also affect measured TFP. However, these cyclical effects should not be at play in correlations between averages over 40 years. Also, the results survive robustness tests, including the exclusion of countries and the utilization of different databases. Table 2 underlines these points by showing estimates for the basic regression of hours (and employment) growth on TFP growth using TED and KLEMS. Across databases, the long-term negative correlation remains robust and quite similar.

Third, although we are focusing on average relationships across the last 40 years rather than cyclical patterns, the negative correlation between TFP growth and hours growth holds up across shorter time periods. Table 3 presents 


\section{Table 4}

\section{Relationship between TFP Growth and Labour Input Growth Excluding Recessions ${ }^{1}$}

\begin{tabular}{l|c|c|c|c}
\multirow{2}{*}{$\begin{array}{l}\text { Database } \\
\text { Input }\end{array}$} & \multicolumn{2}{|c|}{ TED } & \multicolumn{2}{c}{ KLEMS* } \\
\cline { 2 - 5 } Constant & Hours & Employment & Hours & Employment \\
\hline \multirow{2}{*}{ Coefficient } & $1.56^{* * *}$ & $1.87^{* * *}$ & $1.22^{* * *}$ & $1.37^{* * *}$ \\
\cline { 2 - 5 } & $(0.12)$ & $(0.17)$ & $(0.17)$ & $(0.21)$ \\
\hline Observations & $-0.42^{* * *}$ & $-0.54^{* * *}$ & $-0.47^{* * *}$ & $-0.48^{* * *}$ \\
\cline { 2 - 5 } & $(0.10)$ & $(0.12)$ & $(0.12)$ & $(0.14)$ \\
\hline Adjusted $\mathrm{R}^{2}$ & 20 & 20 & 14 & 14 \\
\hline
\end{tabular}

* KLEMS data span the 1980-2007 period; TED data span the 1970-2007 period.

Standard errors in parentheses. ${ }^{* *} p<0.01,{ }^{* *} p<0.05,{ }^{*} p<0.1$

Sources: Total Economy Database, EU KLEMS, and World KLEMS.

1 Sample period excludes all years with at least one month of recession.

\section{Table 5}

\section{Relationship between TFP Growth and Hours Growth Excluding Recessions ${ }^{1}$}

\begin{tabular}{l|c|c|c|c} 
Period & $1970 \mathrm{~s}$ & $1980 \mathrm{~s}$ & $1990 \mathrm{~s}$ & $\mathbf{2 0 0 0 - 2 0 0 7}$ \\
\hline \multirow{2}{*}{ Constant } & $2.49^{* * *}$ & $1.53^{* * *}$ & $1.12^{* * *}$ & $1.53^{* * *}$ \\
\cline { 2 - 5 } & $(0.16)$ & $(0.18)$ & $(0.19)$ & $(0.24)$ \\
\hline \multirow{2}{*}{ Hours Growth } & $-0.64^{* * *}$ & $-0.35^{* *}$ & $-0.24^{*}$ & $-0.91^{* * *}$ \\
\cline { 2 - 5 } & $(0.15)$ & $(0.13)$ & $(0.13)$ & $(0.17)$ \\
\hline Observations & 20 & 20 & 20 & 20 \\
\hline Adjusted R & 0.48 & 0.25 & 0.12 & 0.60 \\
\hline
\end{tabular}

Standard errors in parentheses. ${ }^{* *} p<0.01,{ }^{* *} p<0.05,{ }^{*} p<0.1$

Source: Total Economy Database.

1 Sample period excludes all years with at least one month of recession.

estimates of the correlation using the TED database for the entire period and for each decade individually. Generally, the coefficients are significant, negative, and remarkably similar across decades, although the relationship is less negative and notably weaker in the 1990s. This exception could be the result of a widespread slowdown in European TFP and a pick-up in U.S TFP growth in the 1990s.
Fourth, we also examine whether the negative relation between TFP growth and hours growth is driven by fluctuations around business cycle peaks. To this end, we repeat the exercises described above excluding the years an economy was in recession for at least a month, a procedure which reduces the sample period by about 25 per cent. ${ }^{5}$ The results in Tables 5 and 6 show that the relation holds also for the restricted sample. Indeed, the estimated coefficient is not greatly different than for the full sample, and the fit is somewhat better. In sum, our basic result does not seem to be driven by fluctuations in the business cycle, supporting our intuition that the negative trade-off between TFP and hours is driven by medium- to long-run factors.

\section{Industry-level evidence}

There is considerable variation in the relationship between TFP and hours growth by industry. Combining the EU and World KLEMS databases, we are able to construct correlations of TFP growth and hours growth across decades by industry for 14 countries. ${ }^{6}$ The data are classified into 10 major industry groups: agriculture, mining, manufacturing, electricity, construction, wholesale and retail trade, transportation, hotels and restaurants, finance, and other services (including education and health). Table 6 a presents the industry results together with those for the total economy. The industries are arranged from most negative to least negative correlation between TFP and hours growth. The hotels and restaurants sector appears to have the largest and most significant negative correlation followed by manufacturing and other services. At the other end of the range, TFP and hours in the transpor-

5 In the tables presented here, we removed all years which contained at least 1 month of recession. An alternative exercise that excludes only those years with at least 6 months of recession finds similar results and removes 17 per cent of the sample.

6 The 14 countries are Austria, Canada, France, Germany, Italy, Spain, the United Kingdom, and the United States from the World KLEMS database and Australia, Belgium, Denmark, Finland, Netherlands, and Japan from the EU KLEMS database. 
Table 6a

Relationship between TFP Growth and Hours Growth by Sector, 1980-2007 (OECD 14)

\begin{tabular}{l|c|c|c|c|c} 
Industry & \multicolumn{2}{|c|}{ Coefficient } & \multicolumn{2}{c}{ Constant } & Adjusted $\mathbf{R}^{2}$ \\
\hline Hotels and Restaurants & $-0.60^{* *}$ & $(0.26)$ & 0.28 & $(0.49)$ & 0.25 \\
\hline Manufacturing & -0.46 & $(0.35)$ & $1.19^{* *}$ & $(0.49)$ & 0.05 \\
\hline Total Economy & $-0.37^{* *}$ & $(0.14)$ & $0.74^{* * *}$ & $(0.12)$ & 0.33 \\
\hline Other Services & $-0.35^{*}$ & $(0.19)$ & 0.11 & $(0.30)$ & 0.15 \\
\hline Wholesale and Retail & -0.33 & $(0.48)$ & $1.31^{* * *}$ & $(0.40)$ & -0.04 \\
\hline Financial Services & $-0.23^{*}$ & $(0.12)$ & 0.39 & $(0.41)$ & 0.18 \\
\hline Electricity & -0.23 & $(0.26)$ & $0.81^{* *}$ & $(0.30)$ & -0.02 \\
\hline Agriculture, Forestry, Fishing & -0.21 & $(0.31)$ & $2.77^{* * *}$ & $(0.81)$ & -0.04 \\
\hline Construction & -0.15 & $(0.19)$ & 0.24 & $(0.25)$ & -0.03 \\
\hline Mining and Quarrying & -0.13 & $(0.28)$ & 0.43 & $(1.04)$ & -0.06 \\
\hline Transportation & -0.11 & $(0.37)$ & $1.37^{* * *}$ & $(0.42)$ & -0.08 \\
\hline
\end{tabular}

Standard errors in parentheses. ${ }^{* *} p<0.01,{ }^{* *} p<0.05,{ }^{*} p<0.1$

Number of observations: 14.

Sources: World KLEMS, EU KLEMS.

\section{Table 6b}

Relationship between TFP Growth and Hours Growth by Sector, 1980-2007 (G7)

\begin{tabular}{l|c|c|c|c|c}
\multirow{2}{*}{ Industry } & \multicolumn{2}{|c|}{ Coefficient } & \multicolumn{2}{c|}{ Constant } & Adjusted $\mathbf{R}^{\mathbf{2}}$ \\
\hline Hotels and Restaurants & $-0.99^{* *}$ & $(0.27$ & $1.07^{*}$ & $(0.50)$ & 0.67 \\
\hline Other Services & -0.72 & $(0.36)$ & 0.72 & $(0.50)$ & 0.33 \\
\hline Wholesale and Retail Trade & -0.49 & $(0.48)$ & $1.74^{* * *}$ & $(0.39)$ & 0.01 \\
\hline Manufacturing & $-0.48^{* * *}$ & $(0.12)$ & $1.12^{* * *}$ & $(0.19)$ & 0.73 \\
\hline Total Economy & $-0.47^{* *}$ & $(0.15)$ & $0.78^{* * *}$ & $(0.11)$ & 0.59 \\
\hline Electricity & -0.42 & $(0.44)$ & 0.41 & $(0.47)$ & -0.02 \\
\hline Construction & -0.35 & $(0.38)$ & 0.02 & $(0.43)$ & -0.03 \\
\hline Mining and Quarrying & -0.18 & $(0.24)$ & -1.20 & $(0.96)$ & -0.08 \\
\hline Agriculture, Forestry, Fishing & -0.17 & $(0.66)$ & 3.06 & $(1.86)$ & -0.19 \\
\hline Financial Services & -0.16 & $(0.19)$ & 0.08 & $(0.60)$ & -0.06 \\
\hline Transportation & 0.16 & $(0.69)$ & 0.98 & $(0.79)$ & -0.19 \\
\hline
\end{tabular}

Standard errors in parentheses. ${ }^{* *} p<0.01,{ }^{* *} p<0.05,{ }^{*} p<0.1$

Number of observations: 7.

Sources: World KLEMS, EU KLEMS.

tation, mining, and construction industries are negatively correlated, but the coefficients are much smaller and not different from zero statistically. These results vary somewhat by country group and labour input, as can be seen, for example, in Table $6 \mathrm{~b}$ which presents results for the G-7 countries alone. However, the basic result remains the same: while the cross-country relationship between TFP and labour input is not constant across sectors, it is almost always negative.
The variance across sectors suggests that one possible reason for the long-term divergences across countries in the tradeoff between TFP and hours growth could be differences in countries' industry composition. To check for this effect, we hold industry composition constant by constructing aggregate measures of TFP and hours growth for each country weighting both hours and TFP by the industry value-added shares for the United States. The results in Table 7 show that holding sectoral composition 


\section{Chart 3a}

\section{Relationship between TFP Growth and Hours Growth by Quadrant, 1970-2007}

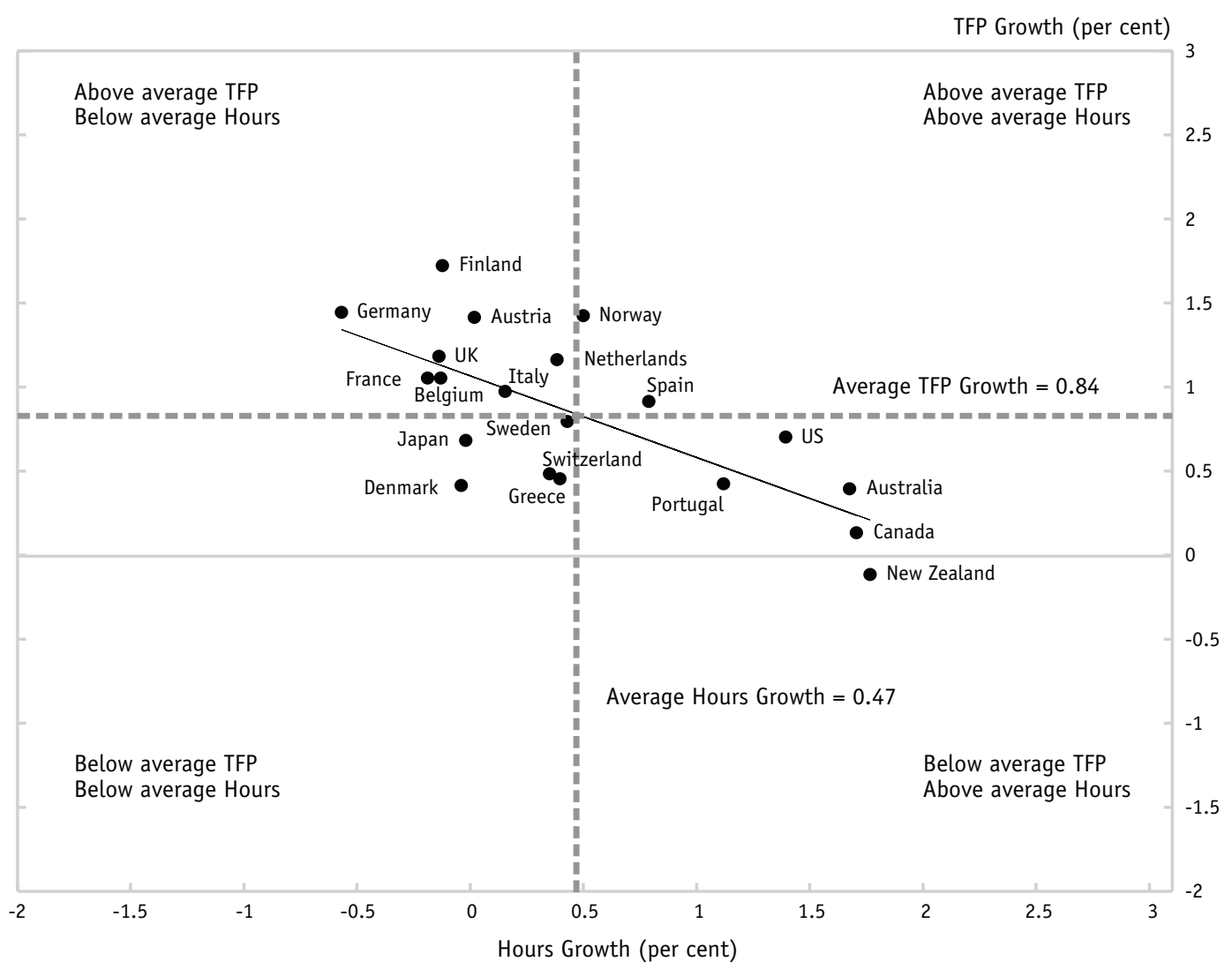

$=-=$ Dotted lines represent the averages over 1970-2007

\section{Table 7}

\section{Relationship between TFP Growth and Hours Growth with U.S. Sectoral Value- Added Weights}

\begin{tabular}{l|c|c} 
& Baseline & $\begin{array}{c}\text { U.S. time- } \\
\text { varying weights }\end{array}$ \\
\hline Constant & $0.74^{* * *}$ & $0.82^{* * *}$ \\
\cline { 2 - 3 } & $(0.12)$ & $(0.13)$ \\
\hline \multirow{2}{*}{ Hours Growth } & $-0.37^{* *}$ & $-0.38^{* * *}$ \\
\cline { 2 - 3 } & $(0.14)$ & $(0.09)$ \\
\hline Observations & 14 & 14 \\
\hline Adjusted R & 0.33 & 0.56 \\
\hline
\end{tabular}

Standard errors in parentheses. *** $p<0.01, * * p<0.05$, * p $<0.1$.

Sources: Authors' calculations and World KLEMS, EU KLEMS. fixed across countries does not change the size and increases the statistical significance of the correlation. This result implies that withinindustry differences across countries (rather than differences in industry composition) are driving the dispersion in the relationship between TFP growth and hours growth, at least at the level of disaggregation considered in our analysis. $^{7}$

\section{Stability of country positions}

We can divide the set of countries into quadrants based on where they fall relative to the sample averages of TFP growth and hours

7 We have also conducted a similar exercise using more disaggregated sectors (with 28 sectors rather than 10) for a smaller set of countries, using the EU KLEMS database only. We find that the negative relation between TFP growth and labour input growth holds and the size of the coefficient does not significantly change. 


\section{Chart 3b}

\section{Relationship between TFP Growth and Hours Growth by Quadrant and by Decade}
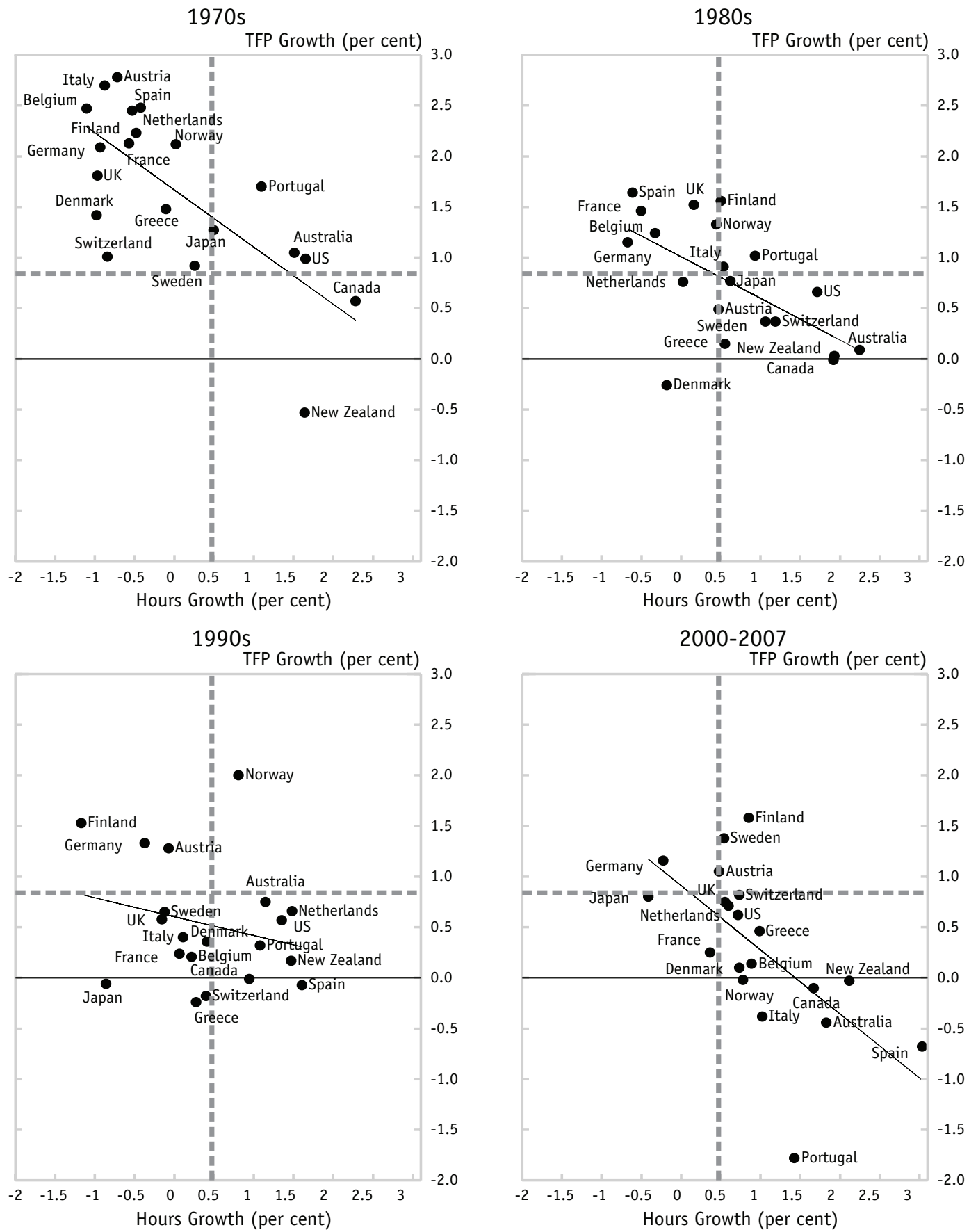

$==$ Dotted lines represent the averages over 1970-2007 on all charts

growth (Chart 3a). Specifically, a number of European countries, importantly Germany and France, have above average TFP growth but below average hours growth. In contrast, countries primarily outside Europe, such as Canada and the United States, have below average TFP growth but stronger-than-average hours growth over the full sample. In the 
other quadrants, Japan stands out as having both low TFP and hours growth.

These groupings are fairly robust across decades (Chart 3b). For the most part, countries do not switch their quadrants dramatically over the almost four decades of our sample. However, there is a notable shift of European countries, even Germany, toward greater employment growth and weaker TFP growth over time. Increased labour utilization and reduced labour productivity growth in Europe have been well documented and have been partly attributed to policies to liberalize labour markets, which reduced labour costs to the firm and lowered disincentives to work resulting in an overall positive labour supply shock (Jackman et al., 2005).

\section{Negative Relationship between Exogenous Changes in Labour Input and TFP Growth}

The results above suggest a robust negative relationship between TFP growth and labour input growth, but they do not provide any indication of causality. Does the negative correlation reflect the fact that exogenous changes in TFP fail to increase aggregate demand and thus result in a decline in hours, as there is less need for labour? Or, do positive changes in hours - possibly through reductions in labour cost or the available supply of labour - lead firms to deemphasize efficiency? To address these questions, we start by trying to identify shocks to hours growth that are independent of TFP growth and use those to instrument for labour input in our baseline regressions.

First, we consider the role of taxes. There is evidence that taxes play an important role in determining the utilization of labour (e.g. Prescott, 2004). By driving a wedge between the marginal product of the worker and the marginal cost of the firm as well as between the marginal effort of the worker and the marginal benefit the worker receives, taxes can reduce both the demand and the supply of labour. Ohanian et al. (2008) find that differences in the tax wedge - a broad measure of taxes that encompasses taxes on income, payroll and consumption - account for much of the variance in hours worked across countries and over time. ${ }^{8}$ However, labour taxes should not directly affect the growth of TFP. With this in mind, we calculate the average tax wedge for each country and use it as an instrument for hours growth. As defined, an increase in our measure of the tax wedge reflects a reduction in the underlying income, payroll, or consumption taxes. As such, an increase in the tax wedge should cause labour input to rise as firm costs or worker disincentives are reduced. Step 1 regression in Table 8 shows that the tax wedge is a good predictor of hours worked, with a highly significant coefficient. ${ }^{9}$ In addition, the sign comes in as expected; lowering taxes, increases the wedge, and increases the growth rate of hours. Moreover, as shown in step 2, our measure of predicted hours using the tax wedge as instrument is significantly negatively correlated with TFP growth. The final table shows that the tax wedge does not have an inde-

8 More formally, the tax wedge $1-\tau_{t}$ is defined as: $1-\tau_{t}=\frac{1-\tau_{h t}}{1+\tau_{c t}}$,

where $\tau_{h t}$ stands for labour income (including payroll) tax and $\tau_{c t}$ for consumption tax. Ohanian et al.

(2008) show that in a standard one-sector real business cycle growth model $1-\tau_{t}$ is equal to the ratio of the marginal rate of substitution between consumption and leisure to the marginal product of labour. Thus, the wedge measures the percentage deviation between the marginal rate of substitution and the marginal product of labour.

9 Data on the tax wedge for 1970-2007 are available for only 15 of the 20 OECD countries earlier considered. 


\section{Table 8}

\section{Relationship between TFP Growth and Hours Growth Using Tax Wedges as an Instrument, 15 OECD Countries}

\section{Step 1 Regression}

Hours Growth vs. Average Tax Wedge by Period

\begin{tabular}{l|c|c|c|c|c} 
Period & $\mathbf{1 9 7 0 - 2 0 0 7}$ & $\mathbf{1 9 7 0 s}$ & $\mathbf{1 9 8 0 s}$ & $\mathbf{1 9 9 0 s}$ & $\mathbf{2 0 0 0 - 2 0 0 7}$ \\
\hline \multirow{2}{*}{ Constant } & $-2.42^{* *}$ & $-4.21^{* *}$ & $-2.88^{*}$ & -1.61 & -0.23 \\
\cline { 2 - 6 } & $(1.00)$ & $(1.82)$ & $(1.35)$ & $(1.19)$ & $(1.33)$ \\
\hline Average Tax Wedge & $4.52^{* *}$ & $6.15^{* *}$ & $5.51^{* *}$ & 3.23 & 1.82 \\
\cline { 2 - 6 } & $(1.60)$ & $(2.69)$ & $(2.14)$ & $(1.96)$ & $(2.21)$ \\
\hline Adjusted R2 & 0.33 & 0.23 & 0.29 & 0.11 & -0.02 \\
\hline
\end{tabular}

Step 2 Regression

TFP Growth vs. Predicted Hours Growth by Period

\begin{tabular}{l|c|c|c|c|c} 
Period & $1970-2007$ & $1970 \mathrm{~s}$ & $1980 \mathrm{~s}$ & $1990 \mathrm{~s}$ & $\mathbf{2 0 0 0 - 2 0 0 7}$ \\
\hline \multirow{2}{*}{ Constant } & $1.22^{* * *}$ & $1.73^{* * *}$ & $1.08^{* * *}$ & $0.75^{* * *}$ & 1.46 \\
\cline { 2 - 6 } & $(0.11)$ & $(0.16)$ & $(0.20)$ & $(0.17)$ & $(0.84)$ \\
\hline Predicted Hours Growth & $-0.71^{* * *}$ & $-0.83^{* * *}$ & -0.37 & $-0.73^{*}$ & -1.13 \\
\cline { 2 - 6 } & $(0.19)$ & $(0.27)$ & $(0.26)$ & $(0.37)$ & $(0.97)$ \\
\hline Adjusted R2 & 0.49 & 0.37 & 0.07 & 0.17 & 0.09 \\
\hline
\end{tabular}

TFP Growth vs. Hours Growth and Average Tax Wedge by Period

\begin{tabular}{l|c|c|c|c|c}
\multirow{2}{*}{ Period } & $1970-2007$ & $1970 \mathrm{~s}$ & $1980 \mathrm{~s}$ & $1990 \mathrm{~s}$ & $\mathbf{2 0 0 0 - 2 0 0 7}$ \\
\hline \multirow{2}{*}{ Constant } & $2.18^{* * *}$ & $3.55^{* * *}$ & 0.63 & $1.69^{*}$ & $1.59^{*}$ \\
\cline { 2 - 6 } & $(0.54)$ & $(1.09)$ & $(0.67)$ & $(0.79)$ & $(0.79)$ \\
\hline \multirow{2}{*}{ Hours Growth } & $-0.31^{* *}$ & $-0.40^{* *}$ & $-0.53^{* * *}$ & -0.14 & $-0.56^{* * *}$ \\
\cline { 2 - 6 } & $(0.12)$ & $(0.14)$ & $(0.12)$ & $(0.17)$ & $(0.17)$ \\
\hline Average Tax Wedge & $-1.79^{*}$ & -2.66 & 0.86 & -1.89 & -1.03 \\
\cline { 2 - 6 } & $(0.90)$ & $(1.60)$ & $(1.11)$ & $(1.34)$ & $(1.35)$ \\
\hline Adjusted R2 & 0.64 & 0.60 & 0.63 & 0.14 & 0.46 \\
\hline
\end{tabular}

Standard errors in parentheses. ${ }^{* * *} p<0.01,{ }^{* *} p<0.05,{ }^{*} p<0.1$

Number of observations: 15.

The tax wedge is equal to (1- tax rate on labour income) $/(1+$ tax rate on consumption expenditures).

Sources: Authors' calculations using TED and McDaniel (2007) datasets.

pendent effect on TFP growth for the 1970s, 1980s, and the 2000-2007 period. However, the tax wedge has a small independent effect - significant only at the 10 per cent level - for the full sample period of 1970-2007, which might invalidate it as an instrument for hours of work in the baseline regression. It is not clear why labour taxes should affect the growth rate of TFP; it may be that our tax wedge variable marginally captures taxes that affect the firm's choice of capital or labour efficiency independent of the cost of labour.
To provide additional support to these results, we use total population growth as an alternative instrument. Demographics have long been understood to be an important driver of labour supply; as such, firms located in countries with faster population growth may choose more hours independently of the technology available to them. However, in principle, population growth should not be linked to changes in total factor productivity. The step 1 results in Table 9 indicate that population growth is a good predictor of hours 


\section{Table 9}

\section{Relationship between TFP Growth and Hours Growth Using Population Growth as an Instrument, 20 OECD Countries}

Step 1 Regression

Hours Growth vs. Population Growth by Period

\begin{tabular}{l|c|c|c|c|c}
\multirow{2}{*}{ Period } & $\mathbf{1 9 7 0 - 2 0 0 7}$ & $\mathbf{1 9 7 0 s}$ & $\mathbf{1 9 8 0 s}$ & $\mathbf{1 9 9 0 s}$ & $\mathbf{2 0 0 0 - 2 0 0 7}$ \\
\hline Constant & $-0.55^{* * *}$ & $-1.31^{* * *}$ & -0.15 & -0.27 & 0.12 \\
\cline { 2 - 6 } & $(0.16)$ & $(0.28)$ & $(0.23)$ & $(0.31)$ & $(0.17)$ \\
\hline Population Growth & $1.80^{* * *}$ & $1.96^{* * *}$ & $1.58^{* * *}$ & $1.22^{* *}$ & $1.58^{* * *}$ \\
\cline { 2 - 6 } & $(0.24)$ & $(0.36)$ & $(0.38)$ & $(0.46)$ & $(0.27)$ \\
\hline Adjusted R2 & 0.75 & 0.61 & 0.46 & 0.24 & 0.64 \\
\hline
\end{tabular}

Step 2 Regression

TFP Growth vs. Predicted Hours Growth by Period

\begin{tabular}{l|c|c|c|c|c} 
Period & $1970-2007$ & $1970 s$ & $1980 s$ & $1990 s$ & $2000-2007$ \\
\hline \multirow{2}{*}{ Constant } & $1.07^{* * *}$ & $1.67^{* * *}$ & $0.97^{* * *}$ & $0.53^{* *}$ & $0.90^{* * *}$ \\
\cline { 2 - 6 } & $(0.11)$ & $(0.16)$ & $(0.18)$ & $(0.20)$ & $(0.28)$ \\
\hline \multirow{2}{*}{ Predicted Hours Growth } & $-0.47^{* * *}$ & $-0.52^{* *}$ & -0.34 & -0.02 & $-0.62^{* *}$ \\
\cline { 2 - 6 } & $(0.15)$ & $(0.20)$ & $(0.21)$ & $(0.34)$ & $(0.25)$ \\
\hline Adjusted R2 & 0.33 & 0.24 & 0.07 & -0.06 & 0.21 \\
\hline
\end{tabular}

TFP Growth vs. Hours Growth and Population Growth by Period

\begin{tabular}{l|c|c|c|c|c}
\multirow{2}{*}{ Period } & $1970-2007$ & $1970 \mathrm{~s}$ & $1980 \mathrm{~s}$ & $1990 \mathrm{~s}$ & $\mathbf{2 0 0 0 - 2 0 0 7}$ \\
\cline { 2 - 6 } & $1.03^{* * *}$ & $1.52^{* * *}$ & $0.94^{* * *}$ & 0.47 & $0.90^{* * *}$ \\
\cline { 2 - 6 } & $(0.21)$ & $(0.39)$ & $(0.18)$ & $(0.28)$ & $(0.24)$ \\
\hline \multirow{2}{*}{ Hours Growth } & $-0.53^{* *}$ & $-0.63^{* * *}$ & $-0.48^{* *}$ & -0.25 & $-0.65^{*}$ \\
\cline { 2 - 6 } & $(0.24)$ & $(0.22)$ & $(0.18)$ & $(0.21)$ & $(0.33)$ \\
\hline \multirow{2}{*}{ Population Growth } & 0.10 & 0.22 & 0.22 & 0.28 & 0.04 \\
\cline { 2 - 6 } & $(0.49)$ & $(0.54)$ & $(0.41)$ & $(0.48)$ & $(0.63)$ \\
\hline Adjusted R & 0.45 & 0.46 & 0.31 & -0.03 & 0.32 \\
\hline
\end{tabular}

Standard errors in parentheses. ${ }^{* *} p<0.01,{ }^{*} p<0.05,{ }^{*} p<0.1$

Number of obsservations: 20.

Sources: Authors' calculations using TED and United Nation datasets.

growth. In step 2, we generally find a negative coefficient on hours growth, although it is a bit smaller (in absolute value) than in the baseline OLS regression (Table 2) using the TED data. In addition, as seen in the third set of results in Table 9, population growth is not statistically significant once it is paired with hours growth as an explanatory variable of TFP growth, indicating that population affects TFP only through hours worked and, thus, appears to be a good instrument for TFP. 10
All told, we find evidence pointing to causality going from hours growth to TFP growth. In particular, it appears that faster population growth leads firms to choose to use more work hours while stressing efficiency less. The evidence from using tax wedge as instrumental variable is a bit more mixed but still supportive. We believe these results call for future research to further confirm the direction of causality between these key macroeconomic variables and the reasons behind it.

10 We also duplicated this result using working age population, rather than total population. 


\section{Chart 4a}

\section{Relationship between Labour Productivity Growth and Hours Growth by Quadrant,}

1970-2007

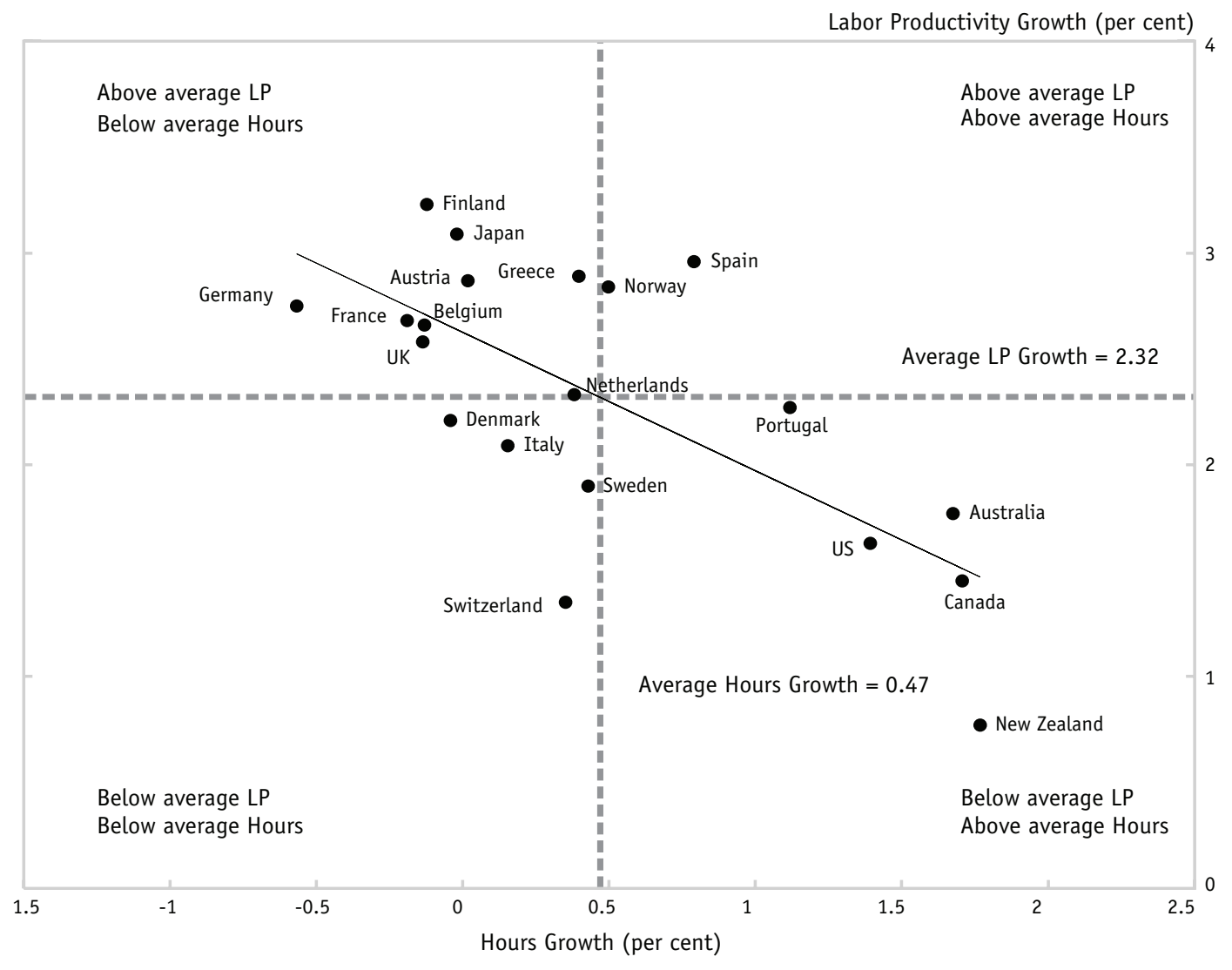

Dotted lines represent the averages over 1970-2007

Robustness Check: Replacing TFP by Labour Productivity

Throughout the article we have focused on TFP growth as the best empirical representation of what macroeconomic theory considers "production efficiency." However, TFP is a derived measure and, even though we believe measurement errors are not driving our results, alternative efficiency measures could generate different results. An easy robustness check is to proxy changes in production efficiency by labour productivity growth, defined as GDP per hour worked.

Labour productivity could be negatively correlated to changes in hours worked in the short-run as labour input is more volatile than capital and underlying TFP changes, but there is no reason to assume that this correlation would be maintained in the medium- to long-run. For instance, as hiring increases following a reduction in unions' wage demands, labour productivity growth would decline. As firms adjust investment to return capital-labour ratios to steady-state values, this initial slowdown in labour productivity would be reversed (Blanchard, 1997, and Estevão, 2007). In this example, the initial wage shock would raise hours growth during the transition phase but keep medium-term labour productivity growth unchanged. In contrast, a negative relationship between the growth in hours and labour productivity growth could remain in the medium term, if, as we argue here, there is a tradeoff 
Chart 4b

Relationship between Labour Productivity Growth and Hours Growth by Quadrant and by Decade

1970s

Labor Productivity per Hour Growth (per cent)

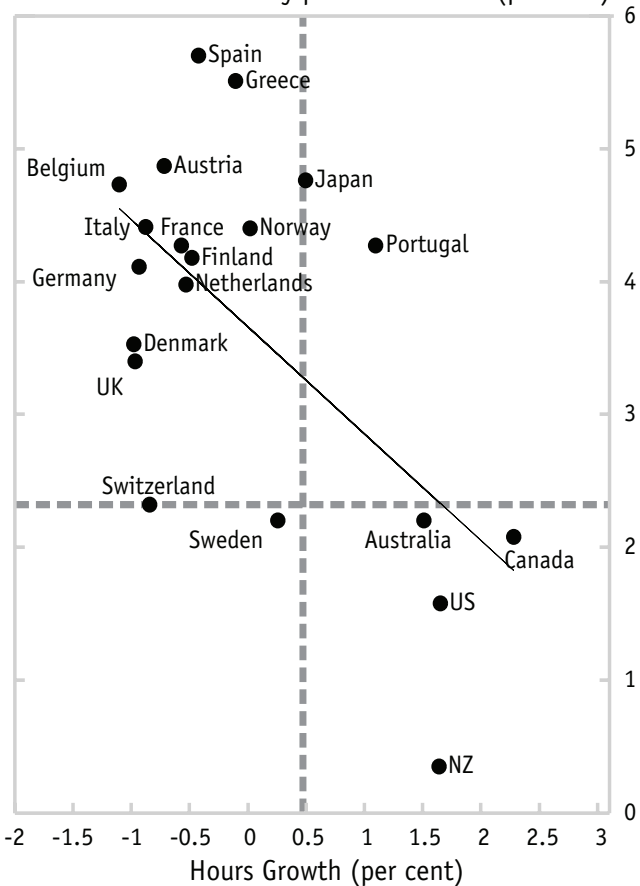

$1990 s$

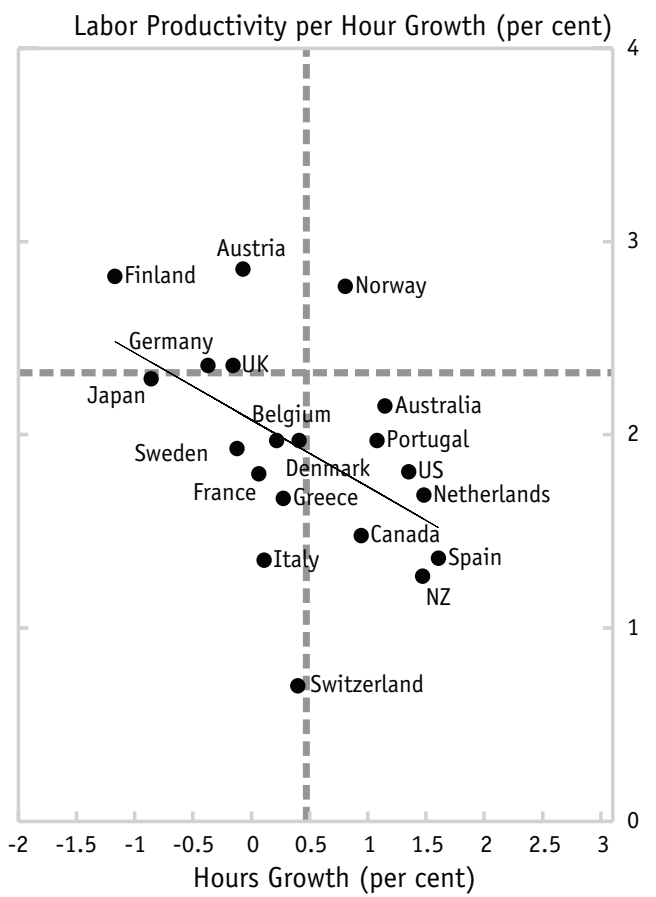

1980s

Labor Productivity per Hour Growth (per cent)

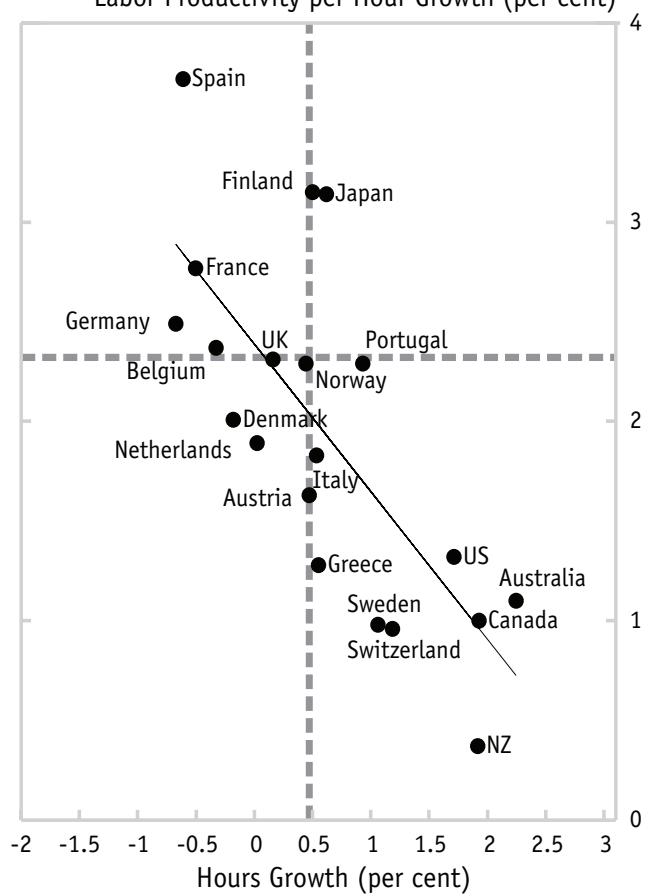

2000-2007

Labor Productivity per Hour Growth (per cent)

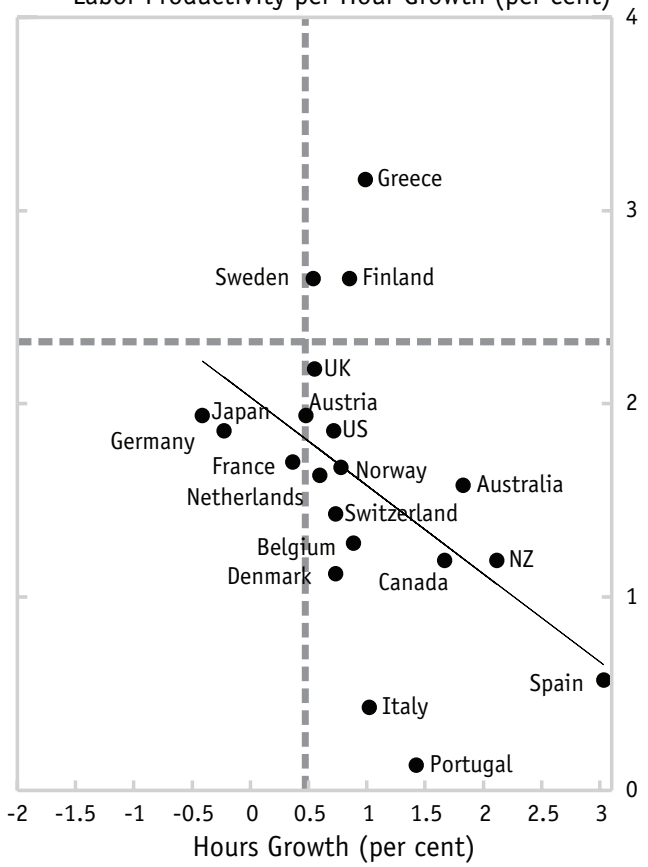

$=-=$ Dotted lines represent the averages over 1970-2007 on all charts 
between investing in efficiency gains (i.e. making TFP grow faster) and using the newly available labour.

Indeed, Chart 4a shows that labour productivity growth is negatively correlated to changes in hours worked in the long run. Moreover, the country ordering in Chart $4 \mathrm{a}$ is similar to the ordering in Chart 1, indicating a close mapping from the relationship between TFP growth and hours growth shown earlier. Chart $4 \mathrm{~b}$ illustrates the same pattern of movement to the lower right quadrant of high hours growth-low productivity growth in the latter part of the sample period as observed in Chart 3b. Our basic instrumental variable regressions for labour productivity growth produce a comparable negative result to the estimations using TFP growth as dependent variable, reaffirming that exogenous changes in hours worked are negatively related to improvements in production efficiency. Using tax wedges (Appendix Table 1) or population growth (Appendix Table 2) as instrumental variables, growth in hours of work affects labour productivity growth negatively for the whole sample period, 1970-2007. The negative relationship is maintained within each of the four decades, although the hours growth coefficient is not always statistically significant.

The sectoral regressions are also similar (Appendix Tables $3 \mathrm{a}$ and $\mathrm{b}$ ), although the coefficients of hours growth tend to be larger and more significant, and the ordering of the sectors changes. As it was the case when using TFP to measure production efficiency, controlling for sectoral composition across countries does not affect the aggregate negative relationship between hours growth and labour productivity growth. ${ }^{11}$

\section{Conclusion}

As economists, we are used to thinking about total factor productivity - a catch-all term for technological advances and improvements in firms' management and organization - as an exogenous determinant of economic growth. Canonical research by Robert Solow over 50 years ago linked TFP to long-run per capita GDP growth and to differences in growth rates across countries (Solow, 1956). Since then, much research has focused on identifying factors that affect TFP such as funding for research and development, barriers to entrepreneurship, and the degree of market regulation. ${ }^{12}$ The labour market impact of TFP growth has been less certain. Traditionally, the response of labour input to changes in TFP depends on a variety of factors, including whether the change is labour saving or labour augmenting and whether the shock in TFP raises aggregate demand (Blanchard et al., 1995). Real business cycle literature has argued that TFP is positively correlated with hours worked, possibly because of labour hoarding or variation in the rate of capacity utilization (Burnside et al., 1995). Other work more related to ours often finds a short- to medium-run negative relationship between hours and labour productivity (not TFP) suggesting that sometimes aggregate demand or investment may not adjust or adjust quickly enough to bring labour productivity growth back to previous rates. ${ }^{13}$

11 All sectoral results are available upon request.

12 See for example, Romer (1990), Holmes and Schmitz (2001), and Acemoglu et al. (2007).

13 For instance, Estevão (2007) shows that the rapid increase in employment in several euro-area countries following a period of wage moderation in the mid-1990s was the main factor behind slower labour productivity growth in the region. However, using a similar framework to the one proposed in Blanchard (1997), the same paper shows that as low wages raise profit rates to a level above the (exogenously given) user cost of capital, investment would rise, capital deepening would speed up, and labour productivity growth would return to its original steady state pace. Dew-Becker and Gordon (2012) documents that investment rates in several euro-area countries have not quite recovered from the wage moderation process, resulting (so far) in a more subdued labour productivity growth path. 
The results in this article tell a somewhat different story. The long-run negative correlation we find between TFP growth and hours growth raises questions about how conclusive Solow's earlier result is in explaining cross-country differences in output performance over the long run. The relatively strong growth performance of Canada in the face of weak TFP growth is a case in point. More generally, the finding that cross-country variance in technology (a key determinant of TFP growth) is significantly greater than the variance in output performance (Comin et. al, 2006) suggests that other factors besides TFP growth must be at play in determining long-run output growth.

Our results also raise questions about the factors that influence TFP growth. We are not arguing that TFP is entirely determined by labour endowment. However, our instrumental variable results point to channels through which firms, industries, and countries may vary the intensity and efficiency with which they utilize labour, depending on labour cost and labour availability. Put another way, the results suggest that studies trying to explain TFP growth by focusing on R\&D investment and institutions could be missing an important variable: the availability of inputs. For instance, having abundant labour could tilt business decisions toward not paying the costs of implementing innovations or reorganizing production that would ultimately result in faster TFP growth. In fact, past work has discussed how the process of introducing new technologies could be costly and interact in nontrivial ways with demographic forces (e.g., Beaudry et al., 2005), but more research on the topic is clearly needed.

These results also suggest that for countries, like Canada, close to the technological frontier with good institutions and adequate support for research, development, and entrepreneurship, concerns about slow TFP growth may be less pressing as long as labour input growth remains strong. In addition, they also suggest that countries which enact policies to reduce the cost of labour or increase immigration should not necessarily be alarmed to find TFP growth slowing-as was the case for a number of European countries during the 1990s. However, if there is a tradeoff between TFP growth and hours growth, as countries face the aging of their population, like Japan, every effort should be made to boost immigration of well-qualified foreign workers and to create an environment where firms and industries can improve technology easily.

Finally, if under certain circumstances there is a tradeoff between TFP growth and hours growth, such as for countries near the production frontier, then there may be social welfare implications of pursuing policies that favor TFP growth over that of hours. Policies that increase production efficiency at the expense of hours of work and/or employment may result in increased unemployment, loss of income for workers, and reduced overall well-being. Indeed, a budding literature (e.g. Layard, 2005) has stressed the large negative effects of joblessness on human happiness.

\section{References}

Acemoglu, Daron, Pol Antras, and Elhanan Helpman (2007) "Contracts and technology adoption," American Economic Review, Vol. 97, pp. 916-43.

Basu, Susantu (1996) "Procyclical productivity: increasing returns or cyclical utilization?" Quarterly Fournal of Economics, Vol. 111, pp. 719-51.

Beaudry, Paul, Fabrice Collard, and David A. Green (2005) "Explaining Productivity Growth: The Role of Demographics," International Productivity Monitor, No. 10, Spring, pp. 45-58.

Blanchard, Olivier (1997) "The Medium Run," Brookings Paper on Economic Activity, Vol. 2, pp. 89-158.

Blanchard, Olivier, Robert Solow, and Beth Anne Wilson (1995) "Productivity and Unemployment," mimeo, MIT.

Burnside, Craig, Martin Eichenbaum, and Sergio Rebelo (1995) "Capital utilization and returns to scale," in NBER Macroeconomics Annual. B.S. Ber- 
nanke and J.J. Rotemberg, eds (Cambridge, MA: MIT Press).

Chen, Vivian, Ben Cheng, Gad Levanon, and Bart van Ark. (2011) "Performance 2011: Productivity, Employment, and Growth in the World's Economies," The Conference Board, Report Number R-1475-11-RR.

Comin, Diego (2008) "Total factor productivity," The New Palgrave Dictionary of Economics, Second Edition, Steven N. Durlauf and Lawrence E. Blume (eds.), Palgrave Macmillan.

Dew-Becker, Ian and Robert J. Gordon (2012) "The Role of Labor Market Changes in the Slowdown of European Productivity Growth," Review of Economics and Institutions, Vol. 3, No. 2, pp. 1-45.

Diewert, Erwin and Emily Yu (2012) "New Estimates of Real Income and Multifactor Productivity Growth for the Canadian Business Sector, 1961-2011," International Productivity Monitor, No. 24, Fall, pp. 27-48.

Estevão, Marcello (2007) "Structural Changes and Labor Productivity Slowdown in the Euro Area," Ensayos, Vol. 25, No. 53, pp. 336-367.

Holmes, Thomas J., and James A. Schmitz, Jr. (2001) "A Gain from Trade: from Unproductive to Productive Entrepreneurship," Fournal of Monetary Economics, Vol. 47, pp. 417-46.

Jackman, Richard, Richard Layard, and Stephen Nickell (2005) Unemployment: Macroeconomic Performance and the Labour Market (New York, NY: Oxford University Press).

Jorgenson, Dale W. (2012) "The World KLEMS Initiative," International Productivity Monitor, No. 24, Fall, pp. 5-19.

Jorgenson, Dale W., Mun Ho, and Jon Samuels (2010) "New Data on U.S. Productivity Growth by Industry," mimeo, Harvard University.
Layard, Richard (2005) Happiness: Lessons from a New Science, Penguin.

McDaniel, Cara (2007) "Average tax rates on consumption, investment, labor and capital in the OECD, 1950-2003," mimeo, University of Arizona.

Ohanian, Lee E., Andrea Raffo, and Richard Rogerson (2008) "Long-Term Changes in Labor Supply and Taxes: Evidence from OECD Countries 1956-2004," Fournal of Monetary Economics, Vol. 55, No. 8, pp. 1353-1362.

O'Mahony, Mary and Marcel P. Timmer (2009) "Output, Input and Productivity Measures at the Industry Level: the EU KLEMS Database," Economic Fournal, Vol. 119(538), F374-F403.

Prescott, Edward C., (2004) "Why Do Americans Work So Much More than Europeans?" Federal Reserve Bank of Minneapolis Quarterly Review, Vol. 28, No. 1, July, pp. 2-13.

Romer, Paul M. (1990) "Endogenous Technological Change," Fournal of Political Economy, Vol. 98. No. 5, October, pp. S71-S 102.

Solow, Robert (1956) "A contribution to the theory of economic growth," Quarterly fournal of Economics, Vol. 70, No. 1, pp. 65-94.

Timmer, Marcel P., Robert Inklaar, Mary O'Mahony, and Bart van Ark (2010) Economic Growth in Europe (Cambridge: United Kingdom: Cambridge University Press).

van Ark, Bart, Gad Levanon, Vivian Chen, and Ben Cheng (2011) "Performance 2011. Productivity, Employment, and Growth in World's Economies," Research Report R-1475-11-RR, The Conference Board. 


\section{Appendix}

\section{Appendix Table 1}

Relationship between Labour Productivity Growth and Hours Growth Using the Tax Wedge as an Instrument, 15 OECD Countries

Step 1 Regression

Hours Growth vs. Average Tax Wedge by Period

\begin{tabular}{l|c|c|c|c|c} 
Period & $1970-2007$ & $1970 s$ & $1980 s$ & $1990 s$ & $\mathbf{2 0 0 0 - 2 0 0 7}$ \\
\hline \multirow{2}{*}{ Constant } & $-2.42^{* *}$ & $-4.21^{* *}$ & $-2.88^{*}$ & -1.61 & -0.23 \\
\cline { 2 - 6 } & $(1.00)$ & $(1.82)$ & $(1.35)$ & $(1.19)$ & $(1.33)$ \\
\hline \multirow{2}{*}{ Average Tax Wedge } & $4.52^{* *}$ & $6.15^{* *}$ & $5.51^{* *}$ & 3.23 & 1.82 \\
\cline { 2 - 6 } & $(1.60)$ & $(2.69)$ & $(2.14)$ & $(1.96)$ & $(2.21)$ \\
\hline Adjusted R2 & 0.33 & 0.23 & 0.29 & 0.11 & -0.02 \\
\hline
\end{tabular}

Step 2 Regression

Labour Productivity per Hour vs. Predicted Hours Growth by Period

\begin{tabular}{l|c|c|c|c|c}
\multirow{2}{*}{ Period } & $1970-2007$ & $1970 \mathrm{~s}$ & $1980 \mathrm{~s}$ & $1990 \mathrm{~s}$ & $2000-2007$ \\
\hline \multirow{2}{*}{ Constant } & $2.60^{* * *}$ & $3.59^{* * *}$ & $2.19^{* * *}$ & $2.11^{* * *}$ & $2.19^{* *}$ \\
\cline { 2 - 5 } & $(0.20)$ & $(0.32)$ & $(0.35)$ & $(0.19)$ & $(0.79)$ \\
\cline { 2 - 6 } & $-0.63^{*}$ & -0.78 & -0.27 & -0.60 & -0.64 \\
\cline { 2 - 6 } & $(0.35)$ & $(0.56)$ & $(0.46)$ & $(0.43)$ & $(0.92)$ \\
\hline Adjusted R2 & 0.14 & 0.06 & -0.05 & 0.06 & -0.04 \\
\hline
\end{tabular}

Labour Productivity per Hour vs. Hours Growth and Average Tax Wedge by Period

\begin{tabular}{|c|c|c|c|c|c|}
\hline Period & $1970-2007$ & 1970 s & $1980 \mathrm{~s}$ & $1990 \mathrm{~s}$ & 2000-2007 \\
\hline \multirow[t]{2}{*}{ Constant } & $2.74^{* *}$ & 3.75 & 0.22 & $2.53^{* * *}$ & $2.25^{* *}$ \\
\hline & $(1.02)$ & $(2.37)$ & $(1.12)$ & $(0.81)$ & $(0.88)$ \\
\hline \multirow[t]{2}{*}{ Hours Growth } & $-0.57^{* *}$ & $-0.75^{* *}$ & $-0.95^{* * *}$ & $-0.34^{*}$ & $-0.42^{* *}$ \\
\hline & $(0.24)$ & $(0.30)$ & $(0.20)$ & $(0.18)$ & $(0.18)$ \\
\hline \multirow[t]{2}{*}{ Average Tax Wedge } & -0.28 & -0.23 & $3.78^{*}$ & -0.84 & -0.40 \\
\hline & $(1.72)$ & $(3.49)$ & $(1.87)$ & $(1.38)$ & $(1.50)$ \\
\hline Adjusted $\mathrm{R}^{2}$ & 0.37 & 0.32 & 0.61 & 0.22 & 0.21 \\
\hline
\end{tabular}

Note: The tax wedge is equal to (1- tax rate on labour income)/(1+ tax rate on consumption expenditures).

Standard errors in parentheses. ${ }^{* * *} p<0.01,{ }^{* *} p<0.05,{ }^{*} p<0.1$

Number of observations: 15.

Sources: Authors' calculations using TED and McDaniel (2007) datasets. 


\section{Appendix Table 2}

Relationship between Labour Productivity Growth and Hours Growth Using Population Growth as an Instrument, 20 OECD Countries

Step 1 Regression

Hours Growth vs. Population Growth by Period

\begin{tabular}{l|c|c|c|c|c}
\multirow{2}{*}{ Period } & $1970-2007$ & $1970 \mathrm{~s}$ & $1980 \mathrm{~s}$ & $1990 \mathrm{~s}$ & $\mathbf{2 0 0 0 - 2 0 0 7}$ \\
\hline \multirow{2}{*}{ Constant } & $-0.55^{* * *}$ & $-1.31^{* * *}$ & -0.15 & -0.27 & 0.12 \\
\cline { 2 - 6 } & $(0.16)$ & $(0.28)$ & $(0.23)$ & $(0.31)$ & $(0.17)$ \\
\hline \multirow{2}{*}{ Population Growth } & $1.80^{* * *}$ & $1.96^{* * *}$ & $1.58^{* * *}$ & $1.22^{* *}$ & $1.58^{* * *}$ \\
\cline { 2 - 6 } & $(0.24)$ & $(0.36)$ & $(0.38)$ & $(0.46)$ & $(0.27)$ \\
\hline Adjusted R2 & 0.75 & 0.61 & 0.46 & 0.24 & 0.64 \\
\hline
\end{tabular}

Step 2 Regression

Labour Productivity per Hour vs. Predicted Hours Growth by Period

\begin{tabular}{l|c|c|c|c|c}
\multirow{2}{*}{ Period } & $\mathbf{1 9 7 0 - 2 0 0 7}$ & $\mathbf{1 9 7 0 \mathrm { s }}$ & $\mathbf{1 9 8 0 \mathrm { s }}$ & $\mathbf{1 9 9 0 \mathrm { s }}$ & $\mathbf{2 0 0 0 - 2 0 0 7}$ \\
\hline Constant & $2.60^{* * *}$ & $3.65^{* * *}$ & $2.26^{* * *}$ & $2.05^{* * *}$ & $2.07^{* * *}$ \\
\cline { 2 - 6 } & $(0.16)$ & $(0.31)$ & $(0.27)$ & $(0.18)$ & $(0.28)$ \\
\hline Predicted Hours Growth & $-0.61^{* * *}$ & -0.56 & -0.52 & -0.27 & $-0.50^{*}$ \\
\cline { 2 - 6 } & $(0.21)$ & $(0.37)$ & $(0.31)$ & $(0.31)$ & $(0.25)$ \\
\hline Adjusted R & 0.28 & 0.06 & 0.08 & -0.01 & 0.13 \\
\hline
\end{tabular}

Labour Productivity per Hour vs. Hours Growth and Population Growth by Period

\begin{tabular}{l|c|c|c|c|c}
\multirow{2}{*}{ Period } & $1970-2007$ & $1970 \mathrm{~s}$ & $1980 \mathrm{~s}$ & $1990 \mathrm{~s}$ & $2000-2007$ \\
\cline { 2 - 6 } & $2.50^{* * *}$ & $2.78^{* * *}$ & $2.19^{* * *}$ & $2.02^{* * *}$ & $2.06^{* * *}$ \\
\cline { 2 - 6 } & $(0.28)$ & $(0.71)$ & $(0.21)$ & $(0.23)$ & $(0.26)$ \\
\cline { 2 - 6 } & $-0.80^{* *}$ & $-1.23^{* * *}$ & $-0.96^{* * *}$ & $-0.38^{* *}$ & -0.38 \\
\cline { 2 - 6 } & $(0.33)$ & $(0.40)$ & $(0.22)$ & $(0.18)$ & $(0.35)$ \\
\cline { 2 - 6 } & 0.35 & 1.31 & 0.69 & 0.13 & -0.18 \\
\hline Popurs Growth & $(0.68)$ & $(0.99)$ & $(0.49)$ & $(0.40)$ & $(0.68)$ \\
\hline Adjusted R2 & 0.43 & 0.36 & 0.55 & 0.16 & 0.14 \\
\hline
\end{tabular}

Standard errors in parentheses. ${ }^{* *} p<0.01,{ }^{* *} p<0.05,{ }^{*} p<0.1$

Number of observations: 20.

Sources: Authors' calculations using TED and United Nation datasets. 
Appendix Table 3a

Relationship between Labour Productivity Growth and Hours Growth by Sector, 19802007 (OECD 14)

\begin{tabular}{l|c|c|c|c|c} 
Industry & \multicolumn{2}{|c|}{ Coefficient } & \multicolumn{2}{c|}{ Constant } & Adjusted R \\
\hline Financial Services & $-0.73^{* *}$ & $(0.18)$ & $3.42^{* * *}$ & $(0.64)$ & 0.53 \\
\hline Transportation & $-0.70^{* * *}$ & $(0.19)$ & $2.38^{* * *}$ & $(0.21)$ & 0.51 \\
\hline Total Economy & $-0.56^{* * *}$ & $(0.16)$ & $2.24^{* * *}$ & $(0.14)$ & 0.46 \\
\hline $\begin{array}{l}\text { Agriculture, Forestry, and } \\
\text { Fishing }\end{array}$ & $-0.54^{* *}$ & $(0.19)$ & 0.29 & $(0.50)$ & 0.35 \\
\hline Wholesale and Retail & $-0.53^{*}$ & $(0.27)$ & $2.17^{* * *}$ & $(0.23)$ & 0.18 \\
\hline Hotels and Restaurants & $-0.51^{* *}$ & $(0.20)$ & $2.38^{* * *}$ & $(0.37)$ & 0.30 \\
\hline Electricity & $-0.49^{*}$ & $(0.23)$ & $2.79^{* * *}$ & $(0.27)$ & 0.21 \\
\hline Other Services & -0.32 & $(0.21)$ & $1.82^{* * *}$ & $(0.33)$ & 0.09 \\
\hline Manufacturing & -0.31 & $(0.24)$ & $1.91^{* * *}$ & $(0.33)$ & 0.05 \\
\hline Construction & -0.20 & $(0.12)$ & $1.74^{* * *}$ & $(0.17)$ & 0.11 \\
\hline Mining and Quarrying & 0.10 & $(0.40)$ & $4.03^{* *}$ & $(1.50)$ & -0.08 \\
\hline
\end{tabular}

Standard errors in parentheses. *** $p<0.01,{ }^{*}$ * $p<0.05, * p<0.1$

Number of observations: 14.

Sources: World KLEMS, EU KLEMS.

\section{Appendix Table 3b}

Relationship between Labour Productivity Growth and Hours Growth by Sector, 19802007(G7)

\begin{tabular}{l|c|c|c|c|c} 
Industry & \multicolumn{2}{|c|}{ Coefficient } & \multicolumn{2}{c|}{ Constant } & Adjusted $\mathbf{R}^{2}$ \\
\hline Financial Services & $-0.99^{* *}$ & $(0.26)$ & $4.19^{* * *}$ & $(0.81)$ & 0.70 \\
\hline Wholesale and Retail & $-0.86^{*}$ & $(0.39)$ & $2.23^{* * *}$ & $(0.32)$ & 0.38 \\
\hline Hotels and Restaurants & $-0.84^{* *}$ & $(0.27)$ & $2.78^{* * *}$ & $(0.50)$ & 0.59 \\
\hline Electricity & $-0.76^{*}$ & $(0.33)$ & $2.93^{* * *}$ & $(0.35)$ & 0.42 \\
\hline Transportation & $-0.75^{* *}$ & $(0.18)$ & $2.19^{* * *}$ & $(0.20)$ & 0.74 \\
\hline Total Economy & $-0.68^{* *}$ & $(0.25)$ & $2.29^{* * *}$ & $(0.19)$ & 0.52 \\
\hline Other Services & -0.55 & $(0.40)$ & $2.33^{* * *}$ & $(0.57)$ & 0.12 \\
\hline Agriculture, Forestry, Fishing & -0.49 & $(0.26)$ & 0.51 & $(0.72)$ & 0.31 \\
\hline Manufacturing & -0.29 & $(0.26)$ & $1.78^{* * *}$ & $(0.42)$ & 0.04 \\
\hline Construction & -0.29 & $(0.26)$ & $1.60^{* * *}$ & $(0.30)$ & 0.03 \\
\hline Mining and Quarrying & -0.27 & $(0.34)$ & 2.38 & $(1.36)$ & -0.07 \\
\hline
\end{tabular}

Standard errors in parentheses. ${ }^{* *} p<0.01,{ }^{* *} p<0.05,{ }^{*} p<0.1$

Number of observations: 7.

Sources: World KLEMS, EU KLEMS. 